\title{
Det beste i Norge - ikke alltid det beste i verden
}

Kvalitet er viktig i alt helsearbeid. Det gjelder både i den rike delen av verden som Norge tilhører, og i den fattige delen av verden, der de fleste mennesker bor. Men innsats for å bedre kvalitet betyr ikke nødvendigvis det samme begge steder. Forskjellene er ofte så store at det som er riktige anbefalinger i én del av verden, kan være ødeleggende i en annen.

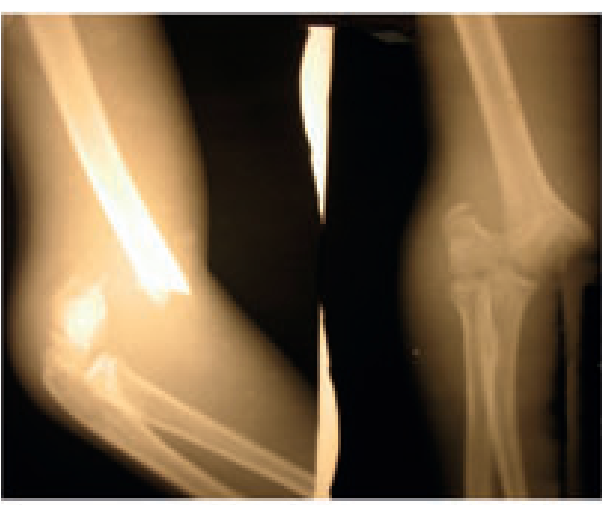

a

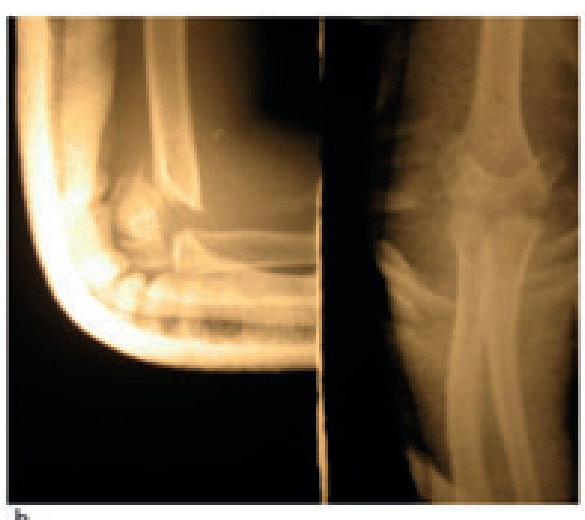

b

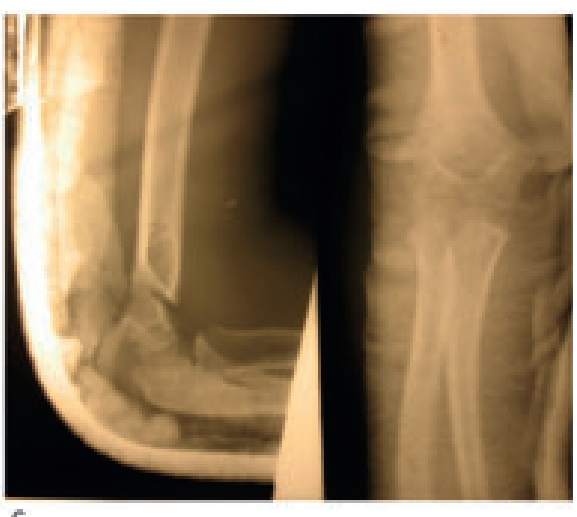

c

Figur 1 Røntgenbilder av albuen til en av våre pasienter. a) fra innleggelsen, b) stillingen etter første reposisjonsforsøk, c) etter andre reposisjon

Dette er velkjent i forbindelse med behandlingsmetoder med direkte effekt på dødelighet i befolkninger. Tilgjengelighet av vanlige antibiotika mot pneumoni på landsbygda $\mathrm{i}$ India er viktigere enn bestemmelse av nøyaktig resistensmønster (1), og promotering av oral rehydreringsvæske mot diaré i Bangladesh er viktigere enn finjustering av intravenøse væskers osmolaritet.

Men problemstillingen over er viktig også i forbindelse med ikke-dødelige til- stander. Jeg vil nedenfor bruke to så forskjellige tilstander som suprakondylære humerusfrakturer og epilepsi hos barn her jeg jobber i Nepal, som eksempler på dette:

\section{Suprakondylære humerusfrakturer} Randsborg \& Sivertsen skrev nylig en god oversiktsartikkel om suprakondylære humerusfrakturer (2). Også på landsbygda i Nepal er dette en vanlig fraktur, selv om både leveforhold og behandlingstilbud er

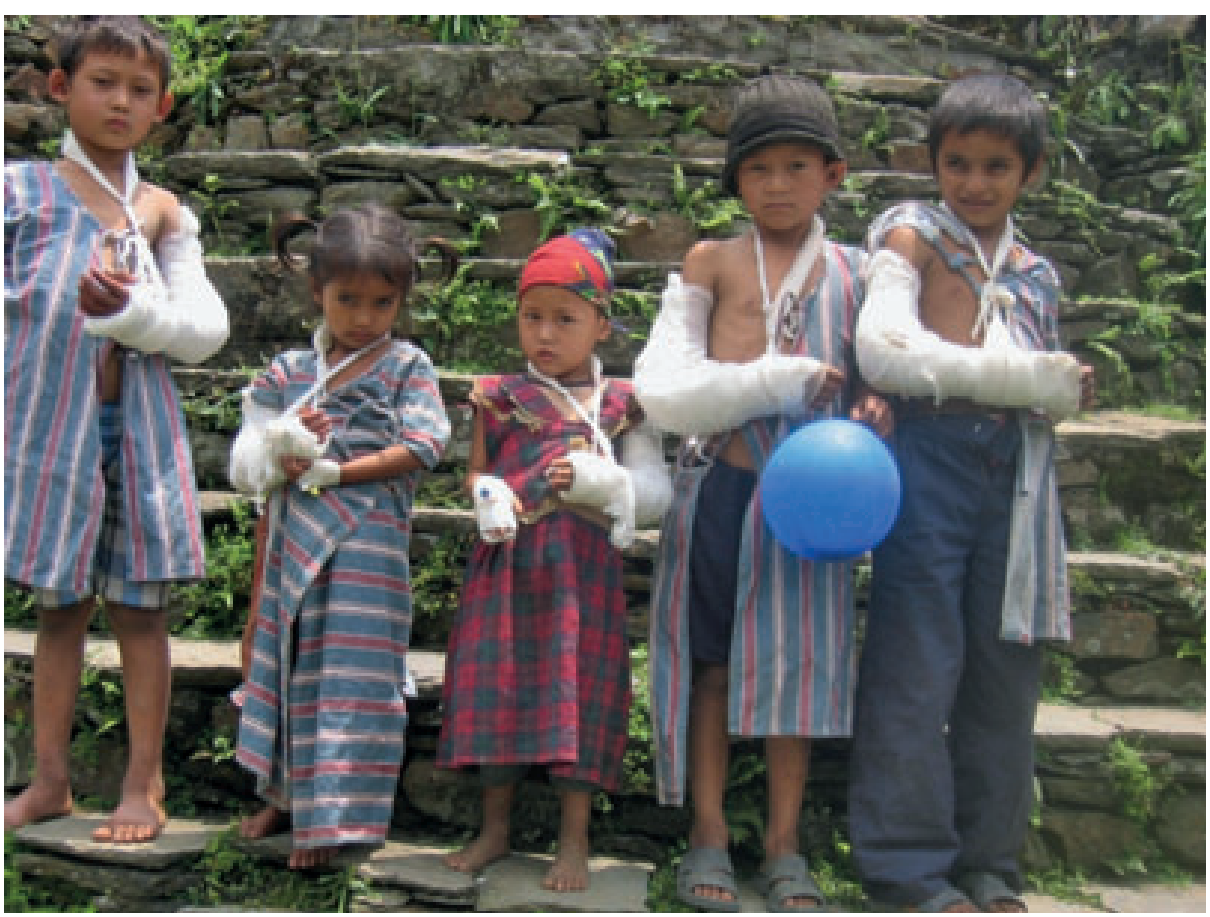

Figur 2 Suprakondylær humerusfraktur er en arbeidsskade hos barn i Nepal. Den viser stor sesongvariasjon. Her er fem barn med denne frakturtypen som var innlagt samtidig hos oss en vårdag svært forskjellige fra Norge (3). Hovedbudskapet $\mathrm{i}$ artikkelen er at perkutan pinning under gjennomlysning gir gode resultater. Om lukket reponering og gipsing skriver de at «behandlingen gir relativt mange komplikasjoner», og at «dessverre er denne metoden vanlig i flere deler av verden». Begge deler er riktige ut fra norske forhold, men må nyanseres på verdensbasis.

Her ved det lille (årsregnskap for hele sykehuset i 2010: ca. 2 millioner kroner) Okhaldhunga sykehus i Nepals fjellverden behandlet vi i fjor i tre åpne og 42 lukkede suprakondylære frakturer av Gartlands type 2 og 3 hos barn. Type 1 registreres ikke $\mathrm{i}$ vårt prosedyreregister, fordi de ikke behandles med noen kirurgisk prosedyre. De lukkede frakturene ble reponert og fiksert med gipslaske. Gjennomlysning er ikke tilgjengelig. Hvis røntgenbilde etter reponering viste uakseptabel stilling etter ett, eventuelt to reponeringsforsøk, ble det gjort åpen kirurgi og fiksering med kryssede pinner. Denne siste behandlingsmetoden blir i artikkelen opplyst å ha betydelige komplikasjoner, og «er derfor ikke å anbefale». Strekkbehandling kunne vært et enkelt og billig alternativ, men siden dette krever lang liggetid, er det vanskelig å motivere pasienter for det (4).

Resultatet er at vi fortsetter å praktisere lukket reponering og fiksering med gips. Dette er vanlig på sykehus i Nepal (5). Indiske studier har vist gode resultater av slik behandling, også helt nylig (6). Alternativet her er ikke pinning under gjennomlysning. Alternativet er det som fremdeles er situasjonen for svært mange barn med denne typen fraktur, nemlig ingen behandling. 
Figur 1 viser røntgenbilder av en av våre pasienter. Kontrollrøntgen etter en uke viste forhold som etter siste reponering, og det samme etter tre uker, da gipslasken ble fjernet. Pasienten fikk ikke optimal medisinsk behandling ut fra norske forhold, men den enkle behandlingen som er tilgjengelig her. Resultatet var likevel klart bedre enn det ville vært uten behandling, og det er godt håp om at han blir arbeidsfør i begge armer. For de fleste barn som får slik fraktur her i Nepal, er det en skade direkte relatert til deres daglige arbeid. De innlegges etter å ha falt ned fra trær eller utfor stup mens de har samlet fòr til familiens husdyr (fig 2). Ubehandlet gir disloserte suprakondylære humerusfrakturer redusert evne til manuelt arbeid resten av livet, en katastrofe i et samfunn der manuelt arbeid gir livsgrunnlag for de fleste.

\section{Epilepsi}

Epilepsi er en annen vanlig, oftest ikke-livstruende tilstand hos barn. Minst $80 \%$ av verdens epileptikere bor i fattige land. De fleste av disse får ikke bare mangelfull behandling. De får ingen medikamentell behandling i det hele tatt (7).

Nepal har nesten 30 millioner innbyggere. En gjennomgang for få år siden viste at det totalt i landet var sju nevrologer, ti CT-maskiner, tre MR-maskiner og fire EEG-maskiner, og at minst to tredeler av epilepsipasientene gikk helt uten behandling (8). Dette står i kontrast til ambisjonene $\mathrm{i}$ en norsk doktorgrad om epilepsibehandling hos barn, der en konklusjon var at «barn med epilepsi bør få individuell oppfølging av et tverrfaglig team som kjenner kompleksiteten i problemene de opplever. De bør følges opp fra et tidlig stadium og over flere år» (9).

Ved Okhaldhunga sykehus hadde vi sist år over 400 konsultasjoner for epilepsi. Vi har kun tre antiepileptika til rådighet: fenobarbiton, fenytoin og karbamazepin. De vanligste komplikasjonene vi ser er brannskader, fordi barna under anfall faller inn i det åpne ildstedet midt på gulvet. I den lokale kulturen her i Øst-Nepal er det husets hellige sentrum og ligger helt ubeskyttet. Slike fall gir ofte dype brannskader med alvorlige sekveler, fordi barna eksponeres for varmen i lengre tid enn ved andre fall. Den aller største utfordringen i epilepsibehandling i Nepal er å bruke billige, tilgjengelige midler til å hindre slike komplikasjoner. Både «individuell oppfølging fra tverrfaglige team» og måling av medikamentelle serumkonsentrasjoner er blindveier i denne sammenheng.

\section{Konklusjon}

Dette illustrerer et viktig generelt poeng: Den største utfordringen innen barnehelsearbeid i verden nå er ikke å finjustere optimale tekniske eller farmakologiske metoder. Det er å gjøre kjente, enkle behandlingsmetoder tilgjengelig for flest mulig barn. Det er foreløpig en mangel på studier av hvordan dette kan gjøres for tilstander som er potensielt invalidiserende, men ikke dødelige.

De norske arbeidene referert over dreide seg ikke om denne problematikken i global sammenheng. Her har jeg likevel benyttet dem til å minne om noe som ofte blir glemt $i$ den rike delen av verden. Internasjonal barnehelse dreier seg om mer enn dødelighetstall.

\section{Erik Bøhler}

bohler@wlink.com.np

Okhaldhunga sykehus

Katmandu

Nepal

Erik Bøhler (f. 1954) er spesialist i barnesykdommer.

Ingen oppgitte interessekonflikter.

Litteratur

1. Sazawal S, Black RE. Meta-analysis of intervention trials on case management of pneumonia in community settings. Lancet 1992; 340: 528-33.

2. Randsborg PH, Sivertsen EA. Suprakondylære humerusfrakturer hos barn. Tidsskr Nor legeforen 2011; 131: 349-52.

3. Bøhler E. Utkantmedisin i Nepal. Tidsskr Nor legeforen 2010; 130: 2506-8

4. Gadgil A, Hayhurst C, Maffuli N et al. Elevated, straight-arm traction for supracondylar fractures of the humerus in children. J Bone Joint Surg (Br) 2005; 87: 82-7

5. Singh RP, Shrivastava MP, Shah RK. Analytical study of the management of supracondylar fracture of children in our setup. Nepal Med Coll J 2006; 8: 276-9.

6. de Gheldere A, Bellan D. Outcome of Gartland type II and type III supracondylar fractures treated by Blount's technique. Indian J Orthop 2010; 44: 89-94.

7. Birbeck GL. Epilepsy care in developing countries Part II of II. Epilepsy Curr 2010; 10: 105-10.

8. Rajbhandari KC. Epilepsy in Nepal. Can J Neurol Sci 2004: 31: 257-60.

9. Feiring E. Små epilepsipasienter med store problemer. Tidsskr Nor Lægeforen 2007; 127: 552.

Mottatt 30.3. 2011, første revisjon innsendt 4.5. 2011, godkjent 12.5. 2011. Medisinsk redaktør Anne Kveim Lie. 